\title{
Effect of Organic Fertilizer Doses on the Plant Growth, Essential Oil Production and Chemical Substances of "Carqueja" over Two Harvest Moments
}

\author{
Daniel Garcia ${ }^{1}$, Paulo Sérgio Siberti da Silva ${ }^{1}$, Marcos Roberto Furlan ${ }^{2}$, Mônica Tiho Chisaki Isobe ${ }^{3}$, Marcia Ortiz \\ Mayo Marques ${ }^{4}$ and Lin Chau Ming ${ }^{1}$ \\ 1. Horticulture Department, Faculty of Agronomic Sciences (FCA), Sao Paulo State University "Júlio de Mesquita Filho", \\ 18.610-307, Botucatu, Sao Paulo, Brazil \\ 2. Agronomy Department, Cantareira Faculty (FIC), 03.020-000, São Paulo, Brazil \\ 3. Agronomy Department, University of Mato Grosso State, 78.200-000, Caceres, Mato Grosso, Brazil \\ 4. Natural Products Department, Agronomic Institute of Campinas (IAC), 13.001-970, Campinas, São Paulo, Brazil
}

\begin{abstract}
This study aimed to investigate, for the first time, the plant growth, essential oil content and their chemical substances of Baccharis trimera (Less.) DC., the first Brazilian variety of medicinal plant, in response to five doses of organic fertilizer (0, 10, 20, 30,40 and 50 ton/ha) over two harvest moments $-120 \mathrm{~d}$ and $242 \mathrm{~d}$ after transplanting (DAT). The work was carried out from February to October 2011 at the experimental farm of the Sao Paulo State University "Julio de Mesquita Filho" (UNESP), Brazil. The seedlings of $B$. trimera var. CPQBA-1 were respectively transplanted into experiment plots under six treatments: $0,10,20,30$, 40 and 50 ton/ha of organic fertilizer. Each treatment had four replications and each plot consisted of 12 plants. Then they were harvested at 120 DAT and 242 DAT, and the essential oil were extracted by hydrodistillation and analyzed by gas chromatograph. The results were subjected to analysis of variance and the means were analysed using Tukey's test (5\%) followed by a regression analysis. The fertilizer dose significantly influenced the height of the plants in the second harvest, while the higher dose of organic fertilizer positively impacted the essential oil content in the first harvest. Also, the level of organic fertilizer was directly correlated with the production of dry matter during the regrowth. Twenty-seven substances were identified in the essential oil samples, and the major components were: bicyclogermacrene, trans-caryophyllene, germacrene-D, spathulenol and caryophyllene oxide. These findings suggest that to obtain higher yields of dry matter of B. trimera, it should be harvested around 242 DAT and organic fertilizer should be applied approximately to 50 ton/ha. Furthermore, higher doses of organic fertilizer and harvest at 120 DAT is able to increase the essential oil content.
\end{abstract}

Key words: Baccharis trimera, Brazilian medicinal plant, dry matter, chemical substances, bicyclogermacrene.

\section{Introduction}

Baccharis trimera (Asteraceae family), popularly known as "carqueja" [1], is a native medicinal plant from Brazil. It is prominent due to its phytochemical potential [2] and ethnopharmacological importance [3]. It is among the 10 most commonly plants sold in Brazil in dried form, and it is also on the list of medicinal plants recommended by Agência Nacional

Corresponding author: Daniel Garcia, Ph.D., research fields: agronomy, medicinal and aromatic plants cultivation, ethnopharmacology. de Vigilância Sanitária (ANVISA) to use in Brazilian hospitals as herbal medicine [4].

Essential oils, sesquiterpene alcohols, resin, vitamins, polyphenols and tannins can be extracted from "carqueja" [5]. It has been scientifically described as a digestive, diuretic, hepatoprotective, hypoglycaemic [6], antiemetic [7], antidiabetic [8], anti-inflammatory and soothing agent [9].

However, despite the great potential for therapeutic application, few agronomic studies focusing mainly in its agronomic factors have been done if compared 
with other medicinal plants, which has hindered the organization of its production [10]. Therefore, the indiscriminate collection of several wild Brazilian medicinal plants has increased, and the quality of these products has been low $[11,12]$.

The high demand for Brazilian medicinal plants by industry is growing up fast and researchers has developed new varieties, such as $B$. trimera var. CPQBA-1, which is the first variety of Brazilian medicinal plant registered by the Ministério da Agricultura, Pecuária e Abastecimento (MAPA) [13]. Thus, agronomic studies with native medicinal plants become important to understand and improve the farming techniques, since it can justify the production of raw material with more desirable properties, such as higher concentration of natural chemical substances [14].

B. trimera var. CPQBA-1 has important agronomic characteristics, such as standard flowering, which makes this variety of interest to industries that require continuous supply of raw material [15], once the active ingredients can change, among other reasons, by the growth stage of the plant $[16,17]$.

Notably, the agronomic responses of B. trimera var.
CPQBA-1 have not been sufficiently studied. Thus, this study aimed to evaluate the growth of $B$. trimera var. CPQBA-1, as well as to evaluate the dry matter yield, essential oil content and accumulation of natural chemical substances in response to five levels of organic fertilizer over two harvests moments.

\section{Materials and Methods}

\subsection{Experiment Site}

The work was carried out from February to October 2011 at the experimental farm of the Sao Paulo State University "Julio de Mesquita Filho" (UNESP), Brazil. The climatic data of the region were recorded during the field work period from the Database of Meteorological for Education and Research, as shown in Fig. 1.

Chemical analysis of the soil in the experiment site was shown in Table 1.

\subsection{Experiment Design}

A voucher of $B$. trimera var. CPQBA-1 was deposited in the Herbarium CPQBA under No. 1286 [18]. First, the seedlings were grown in a greenhouse

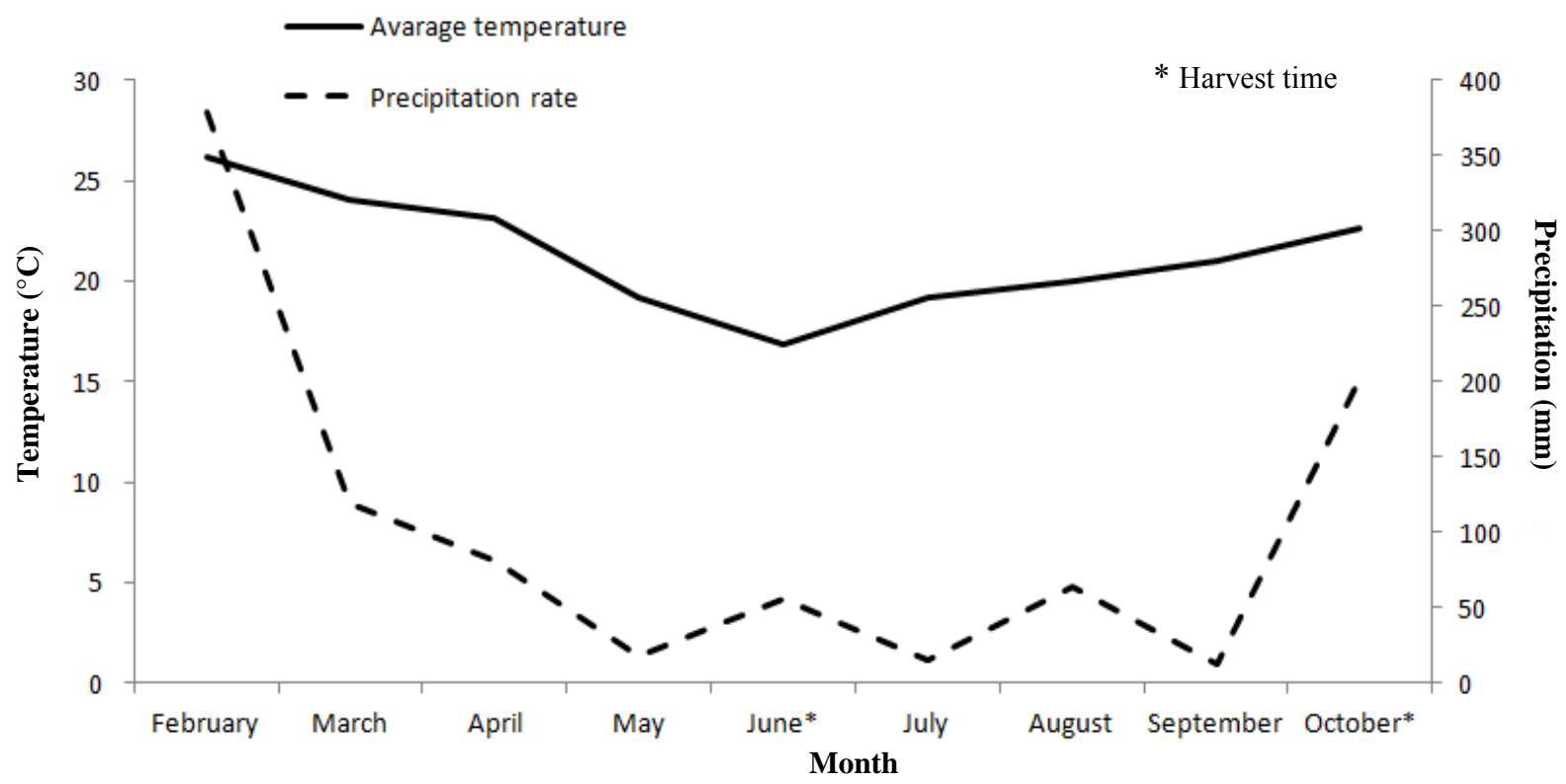

Fig. 1 Temperature $\left({ }^{\circ} \mathrm{C}\right)$ and precipitation rate $(\mathrm{mm})$ during the field work period, 2011.

Source: Database of Meteorological for Education and Research, 2011. 
Table 1 Chemical analysis of the soil in the experiment farm of UNESP, 2011.

\begin{tabular}{ll}
\hline Chemical parameters & Values \\
\hline $\mathrm{pH}$ & 4.7 \\
Organic matter (OM) & $22 \mathrm{~g} / \mathrm{dm}^{3}$ \\
$\mathrm{P}$ & $5 \mathrm{mg} / \mathrm{dm}^{3}$ \\
$\mathrm{H}+\mathrm{Al}$ & $36 \mathrm{mmol} / \mathrm{dm}^{3}$ \\
$\mathrm{~K}$ & $2.7 \mathrm{mmol} / \mathrm{dm}^{3}$ \\
$\mathrm{Ca}$ & $11 \mathrm{mmol} / \mathrm{dm}^{3}$ \\
$\mathrm{Mg}$ & $7 \mathrm{mmol} / \mathrm{dm}^{3}$ \\
Sum of bases $(\mathrm{SB})$ & $21 \mathrm{mmol} / \mathrm{dm}^{3}$ \\
Base saturation $(\mathrm{V} \%)$ & $37 \%$ \\
\hline
\end{tabular}

Table 2 Chemical analysis of organic fertilizer.

\begin{tabular}{ll}
\hline Chemical parameters & Values \\
\hline $\mathrm{pH}$ & 6.9 \\
$\mathrm{OM}$ & $22 \%$ \\
$\mathrm{C}$ & $12 \%$ \\
$\mathrm{C} / \mathrm{N}$ & $14 / 1$ \\
$\mathrm{~N}$ & $9 \mathrm{~g} / \mathrm{kg}$ \\
$\mathrm{K}$ & $14.3 \mathrm{~g} / \mathrm{kg}$ \\
$\mathrm{Ca}$ & $20 \mathrm{~g} / \mathrm{kg}$ \\
$\mathrm{Mg}$ & $5 \mathrm{~g} / \mathrm{kg}$ \\
$\mathrm{P}$ & $2.7 \mathrm{~g} / \mathrm{kg}$ \\
$\mathrm{S}$ & $5.6 \mathrm{~g} / \mathrm{kg}$ \\
$\mathrm{Mn}$ & $231 \mathrm{mg} / \mathrm{kg}$ \\
$\mathrm{B}$ & $17 \mathrm{mg} / \mathrm{kg}$ \\
$\mathrm{Fe}$ & $1,990 \mathrm{mg} / \mathrm{kg}$ \\
$\mathrm{Zn}$ & $89 \mathrm{mg} / \mathrm{kg}$ \\
$\mathrm{Cu}$ & $51 \mathrm{mg} / \mathrm{kg}$ \\
$\mathrm{K}_{2} \mathrm{O}$ & $17 \%$ \\
$\mathrm{CaO}$ & $29 \%$ \\
$\mathrm{MgO}$ & $8 \%$ \\
\hline
\end{tabular}

and watered automatically using a misting system in order to maintain the relative humidity of the environment between $65 \%$ and $75 \%$. After three months, vigorous seedlings were selected and transferred to the experiment plots. The organic fertilizer applied on the same day of transplanting was a mixture of the remains from several medicinal plants (2:3) which had been used to extract the essential oil in the study of Correa et al. [19] and cattle manure dried (1:3). The chemical analysis of organic fertilizer was shown in Table 2.

The experiment was a randomized block design (RBD) with six treatments: 10, 20, 30, 40 and 50 ton/ha of organic fertilizer, including the control without organic fertilizer application ( 0 ton/ha), and each treatment had four replications, totalling 24 plots. Each plot consisted of 12 plants, totalling 288 useful plants. Around each plot, a line of B. trimera var. CPQBA-1 was planted, which were not considered for data collection. The spacing between plants and between rows was $0.6 \mathrm{~m} \times 0.6 \mathrm{~m}$.

Although $B$. trimera is known to usually tolerate several harvests during its cycle, in the current study only two harvest moments (120 DAT and 242 DAT) were considered. The plants were collected in the morning from 7:00 to 9:00 and the cutting height was maintained $10 \mathrm{~cm}$ above the ground.

\subsection{Harvest and Postharvest Process}

After each harvest moment, 12 useful plants of each plot were weighed and then dried in forced air circulation ovens controlled at the temperature of $38^{\circ} \mathrm{C}$ until reached the constant weight [19]. The dry biomass was calculated after the drying stage. The dried plants were stored in non-toxic plastic bag properly identified, and covered by kraft paper bags until the extraction of essential oil.

At the Medicinal Plants Laboratory of UNESP, the essential oil of each plot was extracted by hydrodistillation in a Clevenger apparatus for $2 \mathrm{~h}$ [20], using $80 \mathrm{~g}$ of dried plant immersed in deionized water (2 L). The essential oil was collected with a Pasteur pipette and stored in a properly identified amber flask with a stopper, and its content was calculated using the following Eq. (1), according to Da Silva et al. [21]:

$$
\text { Oil content }(\%)=\frac{\text { weight of extracted oil }}{\text { weight of dry matter }} \times 100 \%
$$

\subsection{Identification and Quantification of Chemical Substances}

The chemical composition of essential oil was analysed using a gas chromatograph coupled to mass spectrometer (GC-MS, Shimadzu QP-5000) equipped 
with a capillary column of fused silica OV-5 (30 $\mathrm{m} \times$ $0.25 \mathrm{~mm} \times 0.25 \mu \mathrm{m}$, Ohio Valley Specialty Chemical, Inc.), operating at $70 \mathrm{eV}$, injector at $240{ }^{\circ} \mathrm{C}$, detector at $230^{\circ} \mathrm{C}$, and split $1 / 20$.

$1 \mu \mathrm{L}$ of essential oil were collected from each one of the 24 plots at 120 DAT and 242 DAT two harvests, respectively, and then solubilized in ethyl acetate (Tedia Brazil, chromatographic grade) $(1 \mu \mathrm{L}$ essential oil/1 mL solvent). The sample injection volume was 1 $\mu \mathrm{L}$, helium was used as carrier gas $(1.0 \mathrm{~mL} / \mathrm{min})$ and temperature program was as the following: $60-95{ }^{\circ} \mathrm{C}$ at $3{ }^{\circ} \mathrm{C} / \mathrm{min}, 95-130{ }^{\circ} \mathrm{C}$ at $8{ }^{\circ} \mathrm{C} / \mathrm{min}, 130-190{ }^{\circ} \mathrm{C}$ at $3{ }^{\circ} \mathrm{C} / \mathrm{min}$ and $190-240{ }^{\circ} \mathrm{C}$ at $10{ }^{\circ} \mathrm{C} / \mathrm{min}$. The analysis was running in triplicate.

The quantification of essential oils by the area normalization method was conducted using a GC with flame ionization detector (GC-FID), adopting the same operational conditions of GC-MS analysis.

The retention index (RI) was obtained by injecting a standard mixture of n-alkanes $\left(\mathrm{C}_{9} \mathrm{H}_{20}-\mathrm{C}_{25} \mathrm{H}_{52}\right.$, Sigma Aldrich, 99\%) according to the equation described by Van Den Dool and Kratz [22]. The identifications of the chemical constituents were conducted by comparative analysis of the mass spectra of the constituents with the database of the CG/EM (Nist 62.lib) system and retention index [23].

Only the volatile substances with an average relative proportion higher than $5 \%$, which are referred as the main substances in this paper, were studied in depth.

\subsection{Statistical Analysis}

Data of height $(\mathrm{cm})$, dry matter $(\mathrm{g})$ and chemical substances were subjected to analysis of variance (ANOVA) and the means were compared by the Tukey's test at $5 \%$ of probability, followed by regression analyzes.

\section{Results and Discussion}

\subsection{Height and Dry Matter Content}

Comparing the height between the two harvest times, higher plants were observed at 242 DAT in the higher fertilization $(57.2 \mathrm{~cm})$.

Regarding the production of dry matter, the highest value $(712.1 \mathrm{~kg} / \mathrm{ha})$ was also detected at plants treated with 50 ton/ha fertilizer at 242 DAT harvest (Fig. 2). These findings showed significant difference of the dry matter content when applied increasing amounts of organic fertilizer to B. trimera var. CPQBA-1, which has already been well-described to several medicinal plants around the world [11]. Comparing the dry matter between two harvest times, the production of the regrowth can be five times larger than the first harvest (Fig. 2).

The results of Tukey's test for dry matter are reinforced by a 2nd degree polynomial regression analysis, which expresses exponential increases in both harvests $\left(R^{2}=0.9553\right.$ at $120 \mathrm{DAT} ; R^{2}=0.9195$ at 242 DAT) in response to the organic fertilizer doses. These results corroborate those reported by Silva et al. [24, 25], who showed that nutrient levels are directly correlated with the dry matter contents of $B$. trimera. Santos et al. [26] also found similar results when examining the effect of increasing organic fertilizer doses on the dry matter content of $B$. dracunculifolia. Although scarce information on the influence of agronomic factors in the chemical substances production by Brazilian medicinal plants and their development in the crop fields, it is well known that the availability of nutrients in the soil solution during its life is able to affect dry matter content [27]. In some cases, the essential oil content is positively correlated with the dose of organic fertilizer. However, inverse relationships for these two factors already have also been reported to other medicinal plants [28-30].

In the current study, it was verified that the dry matter content obtained at 120 DAT was lower than the yield $180 \mathrm{~kg} / \mathrm{ha}$ at $150 \mathrm{DAT}$ presented by Davies [31]. Moreover, the results obtained in the current study drastically differ from those obtained by Palácio et al. [32], who reported higher dry matter content $(4,600 \mathrm{~kg} / \mathrm{ha})$ from $B$. trimera at $180 \mathrm{DAT}$. In this 


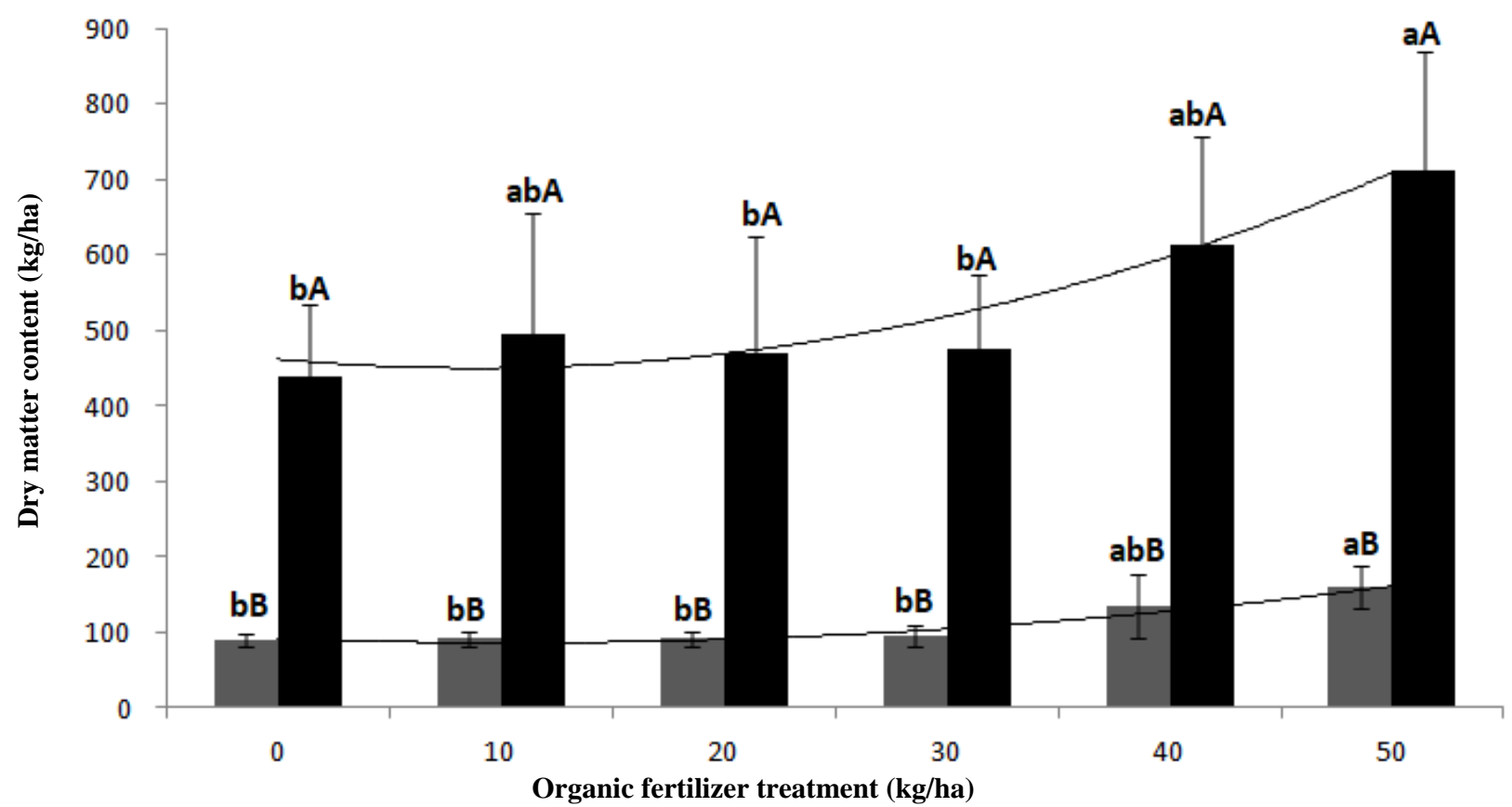

Fig. 2 Dry matter content (kg/ha) of B. trimera var. CPQBA-1 treated with different dose of fertilizer and harvested at 120 DAT (gray color bars) and 242 DAT (black color bars).

The averages followed by the same uppercase letter (120 DAT and 242 DAT) and the same lowercase letter (fertilizer doses) did not differ by Tukey's test $(P>0.05)$.

First harvest at 120 DAT: $y=4.7321 x^{2}-19.154 x+105.1 ; R^{2}=0.9553(\mathrm{CV} \%=21.09)$.

Second harvest or regrowth at 242 DAT: $y=15.268 x^{2}-57.389 x+503.3 ; R^{2}=0.9195(\mathrm{CV} \%=17.94)$.

study, the different doses and sources of nitrogen (urea and sheep manure containing 4,8 and $16 \mathrm{~g}$ $\mathrm{N} /$ plant) were used, which may have influenced the initial capacity of growth. Furthermore, the field work conditions (Paraná, Brazil) may also have influenced the growth. However, in the same study [32], the dry matter content for the same treatment at 270 DAT $(2,900 \mathrm{~kg} / \mathrm{ha})$ was lower than the content of the first harvest $(4,600 \mathrm{~kg} / \mathrm{ha}$ at $180 \mathrm{DAT})$. These findings contradict the higher dry matter content in the second harvest compared with the first harvest observed in the present study. The plant growth also is a factor that can influence the relative proportions of chemical substances [17], as well the essential oil content, for example.

\subsection{Essential Oil Content}

Significant differences of essential oil content were observed between the two harvest moments for all treatments, specifically, but not among organic fertilization treatments. The higher dose of organic fertilization (40 ton $/ \mathrm{ha}$ ) at 120 DAT was the best moment to obtain higher essential oil content (Fig. 3).

This result agrees with the initial capacity for growth of "carqueja" as shown by Palácio et al. [32]. On the other hand, Pocá [33] has reported an inverse relationship between the essential oil contents of $B$. trimera and the increasing doses of fertilizer.

Silva et al. [5] has previously investigated the global yield of $B$. trimera oil, extracted by means of supercritical $\mathrm{CO}_{2}$ at $30{ }^{\circ} \mathrm{C}$ and $40{ }^{\circ} \mathrm{C}$. In this experiment, they got the global yields from $0.34 \%$ to $2.07 \%(\mathrm{w} / \mathrm{w})$.

In the current work, several interferences can have influenced on the essential oil content of B. trimera var. CPQBA-1, such as high pluviometric precipitation and high temperature (Fig. 1). Souza and Lorenzi [34] reported the positive relationship between the average of essential oil content and the organic-mineral fertilizer doses on B. trimera. The quality and quantity 


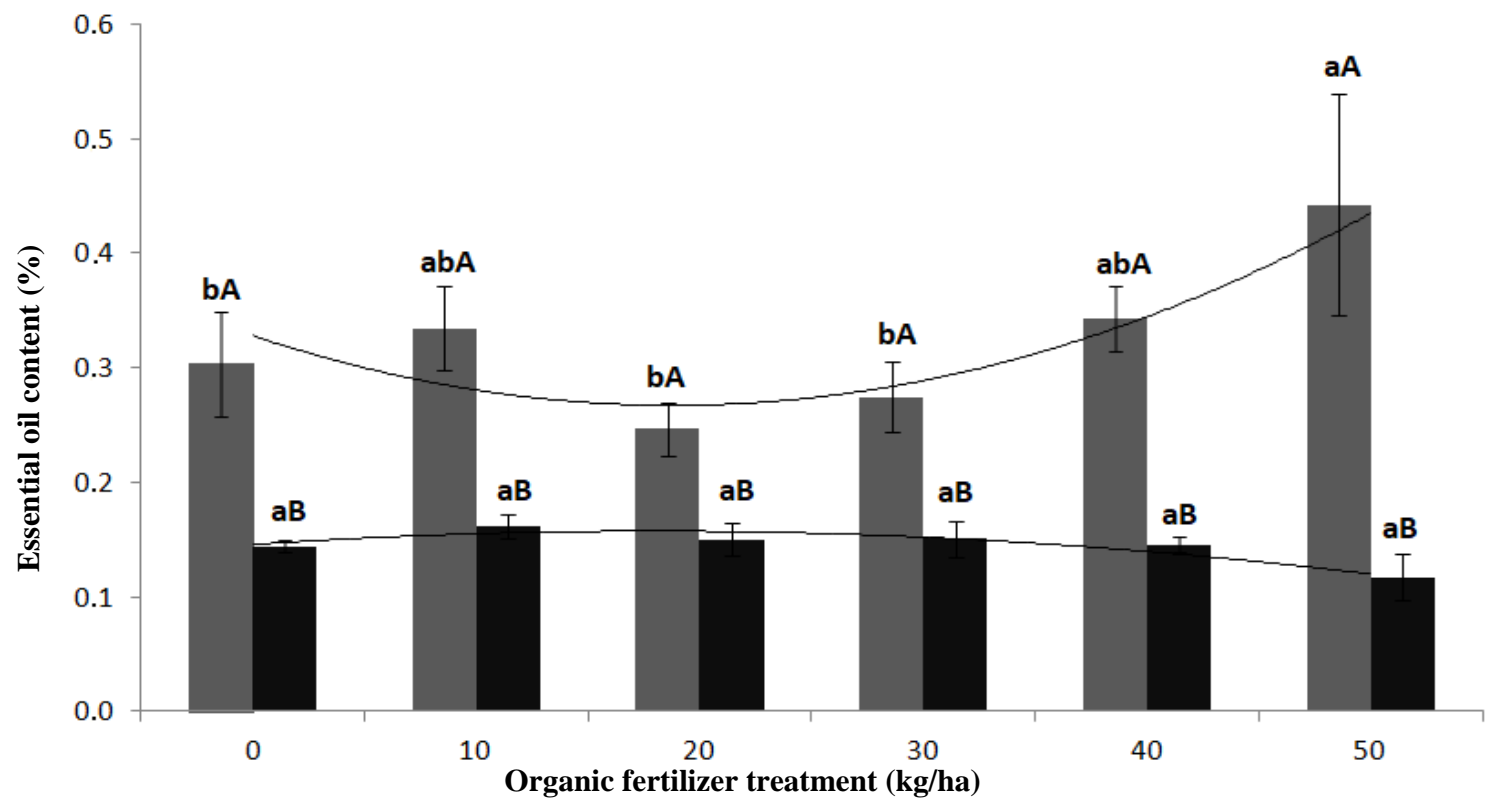

Fig. 3 Essential oil content (\%) extracted from B. trimera var. CPQBA-1 treated with different fertilizer doses and harvested at 120 DAT (gray color bars) and 242 DAT (black color bars).

The averages followed by the same uppercase letter (120 DAT and 242 DAT) and the same lowercase letter (fertilizer doses) did not differ by Tukey's test $(P>0.05)$.

First harvest at 120 DAT: $y=0.0177 x^{2}-0.102 x+0.409 ; R^{2}=0.8231(\mathrm{CV} \%=15.41)$.

Second harvest or regrowth at 242 DAT: $y=-0.0045 x^{2}+0.0252 x+0.121 ; R^{2}=0.9263(\mathrm{CV} \%=15.21)$.

of chemical substances are of great value in the marketing of medicinal plants around the world. The accumulation of these substances in the plant depends on the genetic characteristics of the species, its development stage, its nutritional status, the influence of environmental [16, 17], the biological factors [35] and the post-harvest process [15].

\subsection{Chemical Substances}

The current study identified 27 substances in essential oil samples from $B$. trimera var. CPQBA-1, of which, five were monoterpenes and 22 sesquiterpenes (Table 3). Five chemical substances had average relative proportions higher than 5\%, i.e., bicyclogermacrene, trans-caryophyllene, germacrene-D, spathulenol and caryophyllene oxide.

In the current work, the B. trimera treated with 10 ton/ha of organic fertilizer and harvested at 242 DAT was able to increase the accumulation of trans-caryophyllene (16\%), which is widely used by industry to add flavour to cosmetics and soaps, as well as in many other technical preparations [36]. Mevy et al. [37] observed the antibacterial (Staphylococcus aureus and Enterococcus hirae) and antifungal (Saccharomyces cerevisiae) activity of essential oil extracted from Lippia chevalieri, of which trans-caryophyllene was the major compound (27\%). Furthermore, according to Pinho-da-Silva et al. [36], this substance is present in many plants, and its abundance can vary by plant part.

The content of germacrene-D significantly differed between harvests time, and its accumulation was higher in response to the 50 ton/ha treatment $(15.2 \%$ at 120 DAT and $12.6 \%$ at 242 DAT, respectively) (Table 3). Chialvia and Doglia [38] identified germacrene-D in essential oil of samples from Baccharis genistelloides Pers. (4.3\%). Previous studies have demonstrated the biological activity of this substance [39].

The content of bicyclogermacrene significantly differed among organic fertilizer doses (19.8\%). Moreover, the largest content of bicyclogermacrene 
Table 3 Chemical substances of the essential oil (\%) extracted from B. trimera.

\begin{tabular}{|c|c|c|c|c|c|c|c|c|c|c|c|c|c|}
\hline \multirow{4}{*}{ Substances } & \multicolumn{12}{|c|}{ Substances content $(\%)$ of the essential oil from B. trimera } & \\
\hline & \multicolumn{2}{|c|}{0 ton/ha } & \multicolumn{2}{|c|}{10 ton $/$ ha } & \multicolumn{2}{|c|}{20 ton/ha } & \multicolumn{2}{|c|}{30 ton $/$ ha } & \multicolumn{2}{|c|}{40 ton/ha } & \multicolumn{2}{|c|}{50 ton/ha } & \\
\hline & 120 & 242 & 120 & 242 & 120 & 242 & 120 & 242 & 120 & 242 & 120 & 242 & \\
\hline & & DAT & DAT & DAT & DAT & DAT & DAT & DAT & DAT & DAT & DAT & DAT & \\
\hline \multicolumn{14}{|l|}{ Monoterpenes } \\
\hline$\alpha$-pinene & $0.4^{\mathrm{aA}}$ & $0.7^{\mathrm{aA}}$ & $x$ & $\times$ & $0.3^{\mathrm{aA}}$ & $0.8^{\mathrm{aA}}$ & $0.1^{\mathrm{aB}}$ & $1.2^{\mathrm{aA}}$ & $0.2^{\mathrm{aB}}$ & $1.2^{\mathrm{aA}}$ & $0.1^{\mathrm{aB}}$ & $1.2^{\mathrm{aA}}$ & 933 \\
\hline$\beta$-pinene & $0.7^{\mathrm{aB}}$ & $4.4^{\mathrm{aA}}$ & $1.3^{\mathrm{aB}}$ & $8.8^{\mathrm{aA}}$ & $2.6^{\mathrm{aB}}$ & $5.1^{\mathrm{aA}}$ & $1.7^{\mathrm{aB}}$ & $8.0^{\mathrm{aA}}$ & $3.1^{\mathrm{aB}}$ & $9.0^{\mathrm{aA}}$ & $1.6^{\mathrm{aB}}$ & $6.8^{\mathrm{aA}}$ & 977 \\
\hline Myrcene & $0.4^{\mathrm{aB}}$ & $3.7^{\mathrm{aA}}$ & $0.3^{\mathrm{aB}}$ & $3.8^{\mathrm{aA}}$ & $1.1^{\mathrm{aA}}$ & $2.1^{\mathrm{aA}}$ & $0.8^{\mathrm{aB}}$ & $2.4^{\mathrm{aA}}$ & $1.4^{\mathrm{aB}}$ & $4.6^{\mathrm{aA}}$ & $0.7^{\mathrm{aB}}$ & $3.7^{\mathrm{aA}}$ & 990 \\
\hline Trans- $\beta$-oc & $0.1^{\mathrm{aA}}$ & $0.7^{\mathrm{aA}}$ & $0.2^{\mathrm{aA}}$ & $0.7^{\mathrm{aA}}$ & $0.5^{\mathrm{aA}}$ & $0.3^{\mathrm{aA}}$ & $0.3^{\mathrm{aA}}$ & $0.5^{\mathrm{aA}}$ & $0.4^{\mathrm{aA}}$ & $0.8^{\mathrm{aA}}$ & $0.4^{\mathrm{aA}}$ & $0.7^{\mathrm{aA}}$ & 1,046 \\
\hline Myrtenol & $\times$ & $0.1^{\mathrm{a}}$ & $\times$ & $0.4^{\mathrm{a}}$ & $\times$ & $0.5^{\mathrm{a}}$ & $\times$ & $0.4^{\mathrm{a}}$ & $x$ & $0.3^{\mathrm{a}}$ & $\times$ & $0.2^{\mathrm{a}}$ & 1,195 \\
\hline Total monote & 1.8 & 9.9 & 2.0 & 15.0 & 4.7 & 9.0 & 3.39 & 12.8 & 5.3 & 16.1 & 3.0 & 12.7 & \\
\hline \multicolumn{14}{|l|}{ Sesquiterpenes } \\
\hline$\alpha$-copaene & $0.9^{\mathrm{aA}}$ & $0.6^{\mathrm{aA}}$ & $0.9^{\mathrm{aA}}$ & $0.6^{\mathrm{aA}}$ & $0.7^{\mathrm{aA}}$ & $0.5^{\mathrm{aA}}$ & $0.8^{\mathrm{aA}}$ & $0.4^{\mathrm{aA}}$ & $0.9^{\mathrm{aA}}$ & $0.6^{\mathrm{aA}}$ & $0.9^{\mathrm{aA}}$ & $0.5^{\mathrm{aA}}$ & 1,376 \\
\hline$\beta$-elemene & $1.8^{\mathrm{aA}}$ & $1.5^{\mathrm{aA}}$ & $2.1^{\mathrm{aA}}$ & $1.0^{\mathrm{aA}}$ & $1.8^{\mathrm{aA}}$ & $1.0^{\mathrm{aA}}$ & $1.8^{\mathrm{aA}}$ & $0.9^{\mathrm{aA}}$ & $2.1^{\mathrm{aA}}$ & $1.2^{\mathrm{aA}}$ & $2.1^{\mathrm{aA}}$ & $1.1^{\mathrm{aA}}$ & 1,392 \\
\hline Trans-caryophyllene ${ }^{*}$ & $15.5^{\mathrm{aA}}$ & $14.1^{\mathrm{abA}}$ & $14.6^{\mathrm{aA}}$ & $16.0^{\mathrm{aA}}$ & $15.1^{\mathrm{aA}}$ & $13.2^{\mathrm{abA}}$ & $14.4^{\mathrm{aA}}$ & $12.9^{\mathrm{bA}}$ & $15.7^{\mathrm{aA}}$ & $13.2^{\mathrm{abA}}$ & $15.8^{\mathrm{aA}}$ & $14.0^{\mathrm{abA}}$ & 1,419 \\
\hline Aromadendrene & $1.1^{\mathrm{aA}}$ & $1.6^{\mathrm{aA}}$ & $1.0^{\mathrm{aA}}$ & $1.0^{\mathrm{aA}}$ & $1.0^{\mathrm{aA}}$ & $1.3^{\mathrm{aA}}$ & $1.1^{\mathrm{aA}}$ & $1.2^{\mathrm{aA}}$ & $0.8^{\mathrm{aA}}$ & $1.3^{\mathrm{aA}}$ & $0.9^{\mathrm{aA}}$ & $1.5^{\mathrm{aA}}$ & 1,438 \\
\hline Cis- $\beta$-farnes & $x$ & $\times$ & $\times$ & $\times$ & $\times$ & $\times$ & $\times$ & $\times$ & $x$ & $\times$ & $\times$ & $\times$ & 1,438 \\
\hline$\alpha-h u$ & $1.8^{\mathrm{aA}}$ & $1.5^{\mathrm{aA}}$ & $1.5^{\mathrm{aA}}$ & $1.1^{\mathrm{aA}}$ & $1.6^{\mathrm{aA}}$ & $1.2^{\mathrm{aA}}$ & $1.7^{\mathrm{aA}}$ & $1.0^{\mathrm{aA}}$ & $1.8^{\mathrm{aA}}$ & $1.3^{\mathrm{aA}}$ & $1.8^{\mathrm{aA}}$ & $3.6^{\mathrm{aA}}$ & 1,453 \\
\hline Allo-aromadendrene & $0.2^{\mathrm{aA}}$ & $0.5^{\mathrm{aA}}$ & $0.3^{\mathrm{aA}}$ & $0.4^{\mathrm{aA}}$ & $0.2^{\mathrm{aA}}$ & $0.4^{\mathrm{aA}}$ & $0.4^{\mathrm{aA}}$ & $0.3^{\mathrm{aA}}$ & $0.2^{\mathrm{aA}}$ & $0.5^{\mathrm{aA}}$ & $0.4^{\mathrm{aA}}$ & $0.4^{\mathrm{aA}}$ & 1,460 \\
\hline$\gamma$-muurolene & $1.4^{\mathrm{aA}}$ & $1.3^{\mathrm{aA}}$ & $1.1^{\mathrm{aA}}$ & $1.0^{\mathrm{aA}}$ & $1.1^{\mathrm{aA}}$ & $0.8^{\mathrm{aA}}$ & $1.1^{\mathrm{aA}}$ & $0.7^{\mathrm{aA}}$ & $1.1^{\mathrm{aA}}$ & $1.0^{\mathrm{aA}}$ & $1.3^{\mathrm{aA}}$ & $0.7^{\mathrm{aA}}$ & 1,476 \\
\hline Germ & $11.4^{\mathrm{bA}}$ & $8.2^{\mathrm{bcA}}$ & $11.1^{\mathrm{bA}}$ & $2.6^{\mathrm{dB}}$ & $10.9^{\mathrm{bA}}$ & $9.5^{\mathrm{bA}}$ & $12.0^{\mathrm{abA}}$ & $5.4^{\mathrm{cdB}}$ & $13.5^{\mathrm{abA}}$ & $8.0^{\mathrm{bcB}}$ & $15.2^{\mathrm{aA}}$ & $12.6^{\mathrm{aA}}$ & 1,480 \\
\hline$\beta$-selinene & $0.5^{\mathrm{aA}}$ & $0.5^{\mathrm{aA}}$ & $0.3^{\mathrm{aA}}$ & $0.5^{\mathrm{aA}}$ & $0.3^{\mathrm{aA}}$ & $0.4^{\mathrm{aA}}$ & $0.2^{\mathrm{aA}}$ & $0.6^{\mathrm{aA}}$ & $0.3^{\mathrm{aA}}$ & $0.5^{\mathrm{aA}}$ & $0.2^{\mathrm{aA}}$ & $0.6^{\mathrm{aA}}$ & 1,485 \\
\hline$\gamma$-amo & $0.3^{\mathrm{aA}}$ & $0.4^{\mathrm{aA}}$ & $0.2^{\mathrm{aA}}$ & $2.8^{\mathrm{aA}}$ & $\times$ & $\times$ & $0.1^{\mathrm{aA}}$ & $0.2^{\mathrm{aA}}$ & $\times$ & $\times$ & $0.1^{\mathrm{aA}}$ & $0.5^{\mathrm{aA}}$ & 1,491 \\
\hline Bicyclogermacrene* & $20.9^{\mathrm{aA}}$ & $19.2^{\mathrm{abA}}$ & $21.8^{\mathrm{aA}}$ & $15.8^{\mathrm{bB}}$ & $21.7^{\mathrm{aA}}$ & $18.1^{\mathrm{abA}}$ & $23.9^{\mathrm{aA}}$ & $18.9^{\mathrm{abB}}$ & $22.9^{\mathrm{aA}}$ & $16.7^{\mathrm{abB}}$ & $22.5^{\mathrm{aA}}$ & $19.8^{\mathrm{aA}}$ & 1,496 \\
\hline Trans- $\beta$-guaiene & $\times$ & $\times$ & $\times$ & $\times$ & $\times$ & $\times$ & $\times$ & $\times$ & $\times$ & $\times$ & $\times$ & $\times$ & 1,499 \\
\hline$\gamma$-cadir & $0.9^{\mathrm{aA}}$ & $1.8^{\mathrm{aA}}$ & $1.0^{\mathrm{aA}}$ & $0.7^{\mathrm{aA}}$ & $0.9^{\mathrm{aA}}$ & $0.7^{\mathrm{aA}}$ & $0.8^{\mathrm{aA}}$ & $0.5^{\mathrm{aA}}$ & $0.9^{\mathrm{aA}}$ & $0.7^{\mathrm{aA}}$ & $1.0^{\mathrm{aA}}$ & $1.6^{\mathrm{aA}}$ & 1,513 \\
\hline$\delta$-cadinene & $5.0^{\mathrm{aA}}$ & $3.2^{\mathrm{aA}}$ & $4.8^{\mathrm{aA}}$ & $4.0^{\mathrm{aA}}$ & $4.5^{\mathrm{aA}}$ & $3.4^{\mathrm{aA}}$ & $4.3^{\mathrm{aA}}$ & $2.9^{\mathrm{aB}}$ & $4.9^{\mathrm{aA}}$ & $3.8^{\mathrm{aA}}$ & $4.7^{\mathrm{aA}}$ & $4.6^{\mathrm{aA}}$ & 1,523 \\
\hline$\alpha$-calacorene & $0.3^{\mathrm{aA}}$ & $0.5^{\mathrm{aA}}$ & $0.4^{\mathrm{aA}}$ & $0.4^{\mathrm{aA}}$ & $0.3^{\mathrm{aA}}$ & $0.5^{\mathrm{aA}}$ & $0.1^{\mathrm{aA}}$ & $0.4^{\mathrm{aA}}$ & $0.3^{\mathrm{aA}}$ & $0.4^{\mathrm{aA}}$ & $0.2^{\mathrm{aA}}$ & $0.6^{\mathrm{aA}}$ & 1,541 \\
\hline Germacrene-B & $0.6^{\mathrm{aA}}$ & $0.5^{\mathrm{aA}}$ & $0.6^{\mathrm{aA}}$ & $0.3^{\mathrm{aA}}$ & $0.6^{\mathrm{aA}}$ & $0.4^{\mathrm{aA}}$ & $0.6^{\mathrm{aA}}$ & $0.5^{\mathrm{aA}}$ & $0.4^{\mathrm{aA}}$ & $0.3^{\mathrm{aA}}$ & $0.5^{\mathrm{aA}}$ & $0.6^{\mathrm{aA}}$ & 1,556 \\
\hline Spathulenol* & $10.6^{\mathrm{abA}}$ & $6.2^{\mathrm{bB}}$ & $11.0^{\mathrm{aA}}$ & $17.7^{\mathrm{abA}}$ & $8.9^{\mathrm{abB}}$ & $20.2^{\mathrm{aA}}$ & $9.4^{\mathrm{bA}}$ & $19.1^{\mathrm{abA}}$ & $9.4^{\mathrm{bA}}$ & $6.7^{\mathrm{bA}}$ & $8.8^{\mathrm{cA}}$ & $5.3^{\mathrm{bB}}$ & 1,577 \\
\hline $\begin{array}{l}\text { Caryophyllene } \\
\text { oxide* }\end{array}$ & $5.4^{\mathrm{aA}}$ & $4.6^{\mathrm{abA}}$ & $5.3^{\mathrm{aA}}$ & $6.1^{\mathrm{abA}}$ & $5.3^{\mathrm{aA}}$ & $7.0^{\mathrm{aA}}$ & $5.2^{\mathrm{aA}}$ & $3.5^{\mathrm{abA}}$ & $4.6^{\mathrm{aA}}$ & $5.1^{\mathrm{abA}}$ & $4.5^{\mathrm{aA}}$ & $3.0^{\mathrm{bA}}$ & 1,583 \\
\hline Globulol & $1.8^{\mathrm{aA}}$ & $1.4^{\mathrm{aA}}$ & $1.6^{\mathrm{aA}}$ & $1.2^{\mathrm{aA}}$ & $1.8^{\mathrm{aA}}$ & $1.4^{\mathrm{aA}}$ & $1.9^{\mathrm{aA}}$ & $1.5^{\mathrm{aA}}$ & $1.3^{\mathrm{aA}}$ & $1.2^{\mathrm{aA}}$ & $1.4^{\mathrm{aA}}$ & $0.6^{\mathrm{aA}}$ & 1,590 \\
\hline 1-epi-cubenol & $0.6^{\mathrm{aA}}$ & $0.4^{\mathrm{aA}}$ & $0.5^{\mathrm{aA}}$ & $0.3^{\mathrm{aA}}$ & $0.5^{\mathrm{aA}}$ & $0.2^{\mathrm{aA}}$ & $0.5^{\mathrm{aA}}$ & $0.2^{\mathrm{aA}}$ & $0.4^{\mathrm{aA}}$ & $0.3^{\mathrm{aA}}$ & $\times$ & $\times$ & 1,627 \\
\hline$\alpha$-cadinol & $2.9^{\mathrm{a}}$ & $\times$ & $2.9^{\mathrm{a}}$ & $\times$ & $2.9^{\mathrm{a}}$ & $\times$ & $2.7^{\mathrm{a}}$ & $\times$ & $2.2^{\mathrm{a}}$ & $\times$ & $2.2^{\mathrm{a}}$ & $\times$ & 1,653 \\
\hline Total sesquiterpenes & 82.7 & 67.3 & 82.0 & 73.1 & 79.1 & 84.5 & 81.9 & 70.4 & 83.4 & 62.5 & 84.2 & 71.8 & \\
\hline
\end{tabular}

RI = retention index (Adams, 1995); $\times:<0.04 ; *=$ major substances.

The averages followed by the same uppercase letter (harvests time) and the same lowercase letter (fertilizer treatments) in the line did not differ by Tukey's test $(P>0.05)$.

(23.9\%) was detected at 30 ton/ha at 120 DAT. Lago et al. [40] studied the composition of six species of Baccharis (Southeast of Brazil) and also detected bicyclogermacrene in the essential oil samples. Lebouvier et al. [41] identified that the essential oil from five species of conifer primarily consisted of bicyclogermacrene, and this essential oil was effective as a natural acaricide.
Spathulenol was significantly different between the two harvests moments. The largest accumulation at 120 DAT and 242 DAT (11\% and $20.2 \%$, respectively) was detected at 10 ton/ha and 20 ton/ha. Agostini et al. [42] also detected spathulenol on the essential oils of several species of Baccharis. Silva et al. [43] identified spathulenol and ledol as the main substances of B. trimera grown in the Garden of 
Medicinal Plants at the Federal University of Lavras, Minas Gerais, Brazil. Pocá [33] noted that the spathulenol accumulation was inversely proportional to the dose of manure. Amri et al. [44] observed antibacterial activity of essential oil from three species of Melaleuca (Tunisia).

The average content of caryophyllene oxide did not differ between harvest moments. However, it showed significant difference among organic fertilization doses on the second harvest moment (7\%). According to Marques et al. [45], the presence of caryophyllene derivatives has great ecological importance, since they are natural repellents of leafcutter ants, and caryophyllene oxide is the most efficient of these derivatives in this context. This effect may partly explain the absence of leafcutter ant attacks during the cultivation of B. trimera observed in the current study.

Morais and Castanha [46] obtained similar results to those of this study when evaluating the chemical composition of two populations of "carqueja" (Baccharis sp.) in the state of Rio de Janeiro, Brazil. Specifically, the main substances of essential oil were trans-caryophyllene (22\%), spathulenol (13.8\%), ledol $(13.7 \%)$, caryophyllene oxide $(8.3 \%)$, germacrene-D (7\%) and bicyclogermacrene (8.5\%). In another investigation, Simoes-Pires et al. [47] analysed two species of Baccharis (B. trimera and B. crispa) and obtained opposed chemical results of the current study. Specifically, they highlighted carquejyl acetate, $\beta$-pinene and ledol as the major chemical substances of $B$. trimera and $\alpha$-selinene and spathulenol as the major chemical substances of B. crispa.

Lago et al. [14] studied the differences between the essential oil from female and male specimens of $B$. trimera var. CPQBA-1. They identified the following substances in both genders: $\beta$-elemene, trans-caryophyllene, aromadendrene, bicyclogermacrene, $\delta$-cadinene, germacrene-B, caryophyllene oxide, epi-alpha-muurolol and $\alpha$-cadinol. In samples from female plants, trans-caryophyllene and $\alpha$-cadinene were the major substances (more than 10\%). In male plants, the major substances were the $\alpha$-humulene and germacrene D. Interestingly, carquejol and carquejyl acetate, which are the marker substances of B. trimera [48], were not detected in the essential oils analysed in the current study. Palácio et al. [32] and Lago et al. [14] also did not find this two chemical substances in the samples of essential oil from B. trimera. Palácio et al. [32] believe that these substances may decompose during the extraction process or may be modified by the plant growth conditions.

Specifically in the current work, on one hand there is a good chance that these two chemical substances have been lost on the B. trimera CPQBA-1 during the process to become a variety, since it passed through several crossings with other genetics of B. trimera. On the other hand, there is a notably oscillation on the chemical substances accumulation that can be related to the biotic, abiotic and also genetic factors. The Arnica montana, for example, produces more chemical substances in the juvenile stage, especially helenalin derivatives, while after six weeks of training, the levels of diidrohelenalina type compounds increased significantly and remained constant for a long period [49]. Martins et al. [50] and Furlan [51] suggested harvest at 120 DAT and 180 DAT, respectively. Palácio et al. [32] concluded that in fertile soils, B. trimera does not respond to nitrogen fertilization from organic and mineral resources. Furthermore, the authors have affirmed that the different levels of nitrogen fertilizer (urea and sheep manure containing 4,8 and $16 \mathrm{~g} \mathrm{~N} /$ plant each one) could have promoted changes of the chemical substances. Simões-Pires et al. [47] have identified distance accumulations of major chemical substances in the essential oil of B. trimera harvested at four different times (July, August, September and October): carquejila acetate $(68 \%, 42.3 \%, 60 \%, 58.5 \%)$; $\beta$-pinene $(5.6 \%, 12.6 \%, 11.3 \%, 12.3 \%)$; ledol (5.9\%, $7.2 \%, 7.1 \%, 7.5 \%)$; limonene $(3.4 \%, 4.2 \%, 4.7 \%, 4 \%)$, respectively. 


\section{Conclusions}

In general, from the results of the study, it can be included that the best organic fertilizer content is around 50 ton/ha to get high dry matter (242 DAT) and essential oil content (120 DAT), and there is higher accumulation of bicyclogermacrene at 120 DAT, which is considered as the major chemical substance in this work.

\section{Acknowledgments}

Thanks to Coordination of Improvement of Higher Level Personnel (CAPES) for the financial support and all colleagues who helped in the different stages of this work.

\section{References}

[1] Lorenzi, H., and Matos, F. J. A. 2008. Medicinal Plants in Brazil: Native and Exotic. Nova Odessa: Plantarum Institute for Plant Studies, 512. (in Portuguese)

[2] Karam, T. K., Dalposso, L. M., Casa, D. M., and De Freitas, G. B. L. 2013. "Broom (Baccharis trimera): Therapeutic Use and Biosynthesis." Rev. Bras. Plantas Med. 15 (2): 280-6. (in Portuguese)

[3] Garcia, D., Domingues, M. V., and Rodrigues, E. 2010. "Ethnopharmacological Survey among Migrants Living in the Southeast Atlantic Forest of Diadema, São Paulo, Brazil." J. Ethnobiol. Ethnomed. 6: 29.

[4] Carvalho, A. C. B., Perfeito, J. P. S., Costa e Silva, L. V., Ramalho, L. S., Oliveira Marques, R. F., and Silveira, D. 2011. "Regulation of Herbal Medicines in Brazil: Advances and Perspectives." Braz. J. Pharm. Sci. 47 (3): 467-73.

[5] Silva, D. C. M. N., Bresciani, L. F. V., Dalagnol, R. L., Danielski, L., Yunes, R. A., and Ferreira, S. R. S. 2009. "Supercritical Fluid Extraction of Carqueja (Baccharis trimera) Oil: Process Parameters and Composition Profiles." Food and Bioproducts Processing 87 (4): 317-26.

[6] Soicke, H., and Leng-Peschlow, E. 1987. "Characterisation of Flavonoids from Baccharis trimera and Their Antihepatotoxic Properties." Planta Med. 53 (1): 37-9.

[7] Biondo, T. M., Tanae, M. M., Coletta, E. D., Lima-Landman, M. T., Lapa, A. J., and Souccar, C. 2011. "Antisecretory Actions of Baccharis trimera (Less.) DC. Aqueous Extract and Isolated Compounds: Analysis of Underlying Mechanisms.” J. Ethnopharmacol. 136 (2):
368-73.

[8] Oliveira, A. C., Endringer, D. C., Amorim, L. A., Das Graças, L., Brandão, M., and Coelho, M. M. 2005. "Effect of the Extracts and Fractions of Baccharis trimera and Syzygium cumini on Glycaemia of Diabetic and Non-diabetic Mice.” J. Ethnopharmacol. 102 (3): 465-9.

[9] Gené, R. M., Cartaña, C., Adzet, T., Marín, E., Parella, T., and Cañigueral, S. 1996. "Anti-inflammatory and Analgesic Activity of Baccharis trimera: Identification of Its Active Constituents." Planta Med. 62 (3): 232-5.

[10] Souza, M. R. M., Pereira, R. G. F., and Fonseca, M. C. M. I. 2012. "Commercialization of Medicinal Plants in the Context of the Production Chain in Minas Gerais." Rev. Bras. Plantas Med. 14: 242-5. (in Portuguese)

[11] Retta, D., Dellacassa, E., Villamil, J., Suárez, S. A., and Bandoni, A. L. 2012. "Marcela, a Promising Medicinal and Aromatic Plant from Latin America: A Review." Ind. Crops Prod. 38: 27-38.

[12] Furlan, M. R., and Garcia, D. 2013. "The Production of Medicinal Plants and Herbal Medicine: Past, Present and Future." In UNIFAR, 1913-2013: The History of a Secular Institution, edited by Soares-Neto, J. A. R., and Souza, M. T. São Paulo: RS Press, 131. (in Portuguese)

[13] Montanari Jr., I., Pereira, B., and Mello, W. C. 2008. "First Record of Native Medicinal Plant Cultivar in Brazil." Horti. Bras. 26: 3109-12. (in Portuguese)

[14] Lago, J. H. G., Romoff, P., Fávero, O. A., Souza, F. O., Soares, M. G., Baraldi, P. T., and Corrêa, A. G. 2008. "Chemical Composition of Male and Female Baccharis trimera (Less.) DC. (Asteraceae) Essential Oils." Biochem. Syst. Ecol. 36 (9): 737-40.

[15] Correa Junior, C., Graça, L. R., and Scheffer, M. C. 2004. Agroindustrial Complex of Medicinal, Aromatic and Spicy Plants in the State of Paraná: Diagnosis and Perspectives. Curitiba, Brazil: Embrapa, 272. (in Portuguese)

[16] Taiz, L., and Zeiger, E. 2009. Plant Physiology, 4th ed.. Sunderland, MA: Sinauer Associates, 764.

[17] Gobbo-Neto, L., and Lopes, N. P. 2007. "Medicinal Plants: Factors Influencing the Content of Secondary Metabolites." Quím. Nova. 30 (2): 374-81. (in Portuguese)

[18] Montanari Junior, I. 2002. "Aspects of Commercial Production of Native Medicinal Plants." CPQBA-UNICAMP, Campinas, SP. Accessed August 16, 2002. http://www.cpqba.unicamp.br/plmed/artigos/ producao.htm. (in Portuguese)

[19] Correa Junior, C., Ming, L. C., and Scheffer, M. C. 2006. Agroecological Cultivation of Medicinal, Aromatic and Spicy Plants. Brasília: Ministry of Agrarian Development, 75. (in Portuguese) 

Chemical Substances of "Carqueja" over Two Harvest Moments

[20] Craveiro, A. A., Fernandes, A. G., Andrade, C. H. S., Matos, F. J. A., Alencar, J. W., and Machado, M. I. L. 1981. Northeastern Plant Essential Oils. Fortaleza: UFC, 209. (in Portuguese)

[21] Da Silva, E. A. J., Da Silva, V. P., Alves, C. C. F., Alves, J. M., Souchie, E. L., and Barbosa, L. C. A. 2016. "Harvest Time on the Content and Chemical Composition of Essential Oil from Leaves of Guava." Cienc. Rural 46 (10): 1771-6.

[22] Van Den Dool, H., and Kratz, P. D. 1963. "A Generalization of the Relation Index System Including Liner Temperature Programmed Gas-Liquid Partition Chromatography." J. Chromatogr. 11: 463-71.

[23] Adams, R. P. 2007. Identification of Essential Oil Components by Gas Chromatography/Mass Spectrocopy. Illinois, USA: Allured Publishing Corporation, 468.

[24] Silva, F. G., Pinto, J. E. B. P., Cardoso, M. G., Nascimento, E. A., Nelson, D. L., Sales, J. F., and Mol, D. J. S. 2006. "Influence of Radiation Level on Plant Growth, Yield and Quality of Essential Oil in Carqueja." Ciên. Agrotecnol. 30 (1): 52-7.

[25] Silva, F. G., Pinto, J. E. B. P., Cardoso, M. G., Sales, J. F., Mol, D. J. S., and Divino, S. P. 2007. "Influence of Manure and Fertilizer on Baccharis trimera (Less.) D.C. Growth and Essential Oil Yield." J. Herbs, Spices, Med. Plants 13: 83-92.

[26] Santos, R. F., Lima, L., Altivo, F. S., Lalla, J. G., and Ming, L. C. 2011. "Phytomass Production, Content and Productivity of Essential Oil of Baccharis dracunculifolia as Affected by Organic Fertilization." Rev. Bras. Plantas Med. 13: 574-81. (in Portuguese)

[27] Cortés, A. M. P., Biasi, L. A., Monte-Serrat, B., and Nakashima, T. 2007. "Nutrient Extraction for Shoots of Carqueja under Sources and Levels of Nitrogen." Ciência Rural 37 (6): 1809-12. (in Portuguese)

[28] Ming, L. C. 1992. "Influence of Different Levels of Organic Fertilization on Biomass Production and Essential Oil Content of Lippia alba (Mill.) N.E.Br., Verbenaceae." Master dissertation, Federal University of Paraná, Curitiba. (in Portuguese)

[29] Corrêa, R. M., Pinto, J. E. B. P., Reis, E. S., Costa, L. C. B., Alves, P. B., Niculan, E. S., and Brant, R. S. 2010. "Organic Fertilization on Phytomass Production and Essential Oil Content and Quality of Oregano (Origanum vulgare L.) under Protected Cultivation." Rev. Bras. Plantas Med. 12 (1): 80-9. (in Portuguese)

[30] Souza, M. F., Souza Junior, I. T., Gomes, P. A., Fernandes, L. A., Martins, E. R., Costa, C. A., and Sampaio, R. A. 2010. "Liming and Organic Fertilization on Lippia citriodora (Kunth) Phytomass and Essential Oil Production." Rev. Bras. Plantas Med. 12 (4): 401-5. (in Portuguese)
[31] Davies, P. 1999. "Experimentation on the Propagation of Baccharis trimera (Less.) DC., Compositae (Carqueja)." Acta Hortic. 502: 117-20.

[32] Palácio, C. P. A. M., Biasi, L. A., Nakashima, T., and Serrat, B. M. 2007. "Biomass and Essential Oil of Carqueja (Baccharis trimera (Less) DC.) under the Influence of Sources and Doses of Nitrogen." Rev. Bras. Plantas Med. 9 (3): 58-63. (in Portuguese)

[33] Pocá, A. M. P. C. 2005. "Biomass, Essential Oil, Phytochemical Profile and Nutrients of the Carqueja under the Influence of Factors and Doses of Nitrogen." Master dissertation, Federal University of Paraná, Paraná. (in Portuguese)

[34] Souza, V. C., and Lorenzi, H. 2005. "Asteraceae (Compositae)." In Systematic Botany: Illustrated Guide for the Identification of Angiosperm Families of the Brazilian Flora, Based on APG II. New Odessa: Institute Plantarum, 572-601. (in Portuguese)

[35] Mann, J. 1987. Secondary Metabolism, 2nd ed.. Oxford: Oxford University Press.

[36] Pinho-da-Silva, L., Mendes-Maia, P. V., Teófilo, T. M. N. G., Barbosa, R., Ceccatto, V. M., Coelho-de-Souza, A. N., Cruz, J. S., and Leal-Cardoso, J. H. 2012. "Trans-caryophyllene, a Natural Sesquiterpene, Causes Tracheal Smooth Muscle Relaxation through Blockade of Voltage-Dependent $\mathrm{Ca}^{2+}$ Channels.” Molecules 17 (10): 11965-77.

[37] Mevy, J. P., Bessiere, J. M., Dherbomez, C., Millogo, J., and Viano, J. 2007. "Chemical Composition and Some Biological Activities of the Volatile Oils of a Chemotype of Lippia chevalieri Moldenke.” Food Chemistry 101 (2): 682-5.

[38] Chialva, F., and Doglia, G. 1990. "Essential Oil from Carqueja (Baccharis genistelloides Pers.)." Journal of Essential Oil Research 2 (4): 173-7.

[39] Francescato, L. N., Deuschle, R. A. N., and Mallmann, C. A. 2007. "Antimicrobial Activity of Senecio heterotrichius DC. (Asteraceae).” Rev. Bra. Ciên. Farm. 43 (2): 239-45. (in Portuguese)

[40] Lago, J. H. G., Romoff, P., Fávero, O. A., Soares, M. G., Baraldi, P. T., Corrêa, A. G., and Souza, F. O. 2008. "Composition of the Essential Oils of Six Species of the Baccharis Genus of 'Campos de Altitude' of the Atlantic Forest of Paulista." Quimica Nova 31 (4): 727-30. (in Portuguese)

[41] Lebouvier, N., Hue, T., Hnawia, E., Lesaffre, L., Menut, C., and Nour, M. 2013. "Acaricidal Activity of Essential Oils from Five Endemic Conifers of New Caledonia on the Cattle Tick Rhipicephalus (Boophilus) Microplus." Parasitol. Res.112 (4): 1379-84.

[42] Agostini, F., Santos, A. C. A., Rossato, M., Pansera, M. R., Zattera, F., Wasum, R., and Serafini, L. A. 2005. 
"Studies on the Essential Oils from Several Baccharis (Asteraceae) from Southern Brazil." Rev. Bras. Farmacogn. 15 (3): 215-9. (in Portuguese)

[43] Silva, F. G., Nascimento, V. E., Pinto, J. E. B. P., Oliveira, C. B. A., Santos, M. R., and Ferri, P. H. 2010. "Influence of Postharvest Processing and Storage on Chemical Composition of Drug and Essential Oil from Carqueja (Baccharis trimera (Less.) DC.)." Rev. Bras. Plantas Med. 12 (4): 436-42. (in Portuguese)

[44] Amri, I., Mancini, E., De Martino, L., Marandino, A., Lamia, H., Mohsen, H., Bassem, J., Scognamiglio, M., Reverchon, E., and De Feo, V. 2012. "Chemical Composition and Biological Activities of the Essential Oils from Three Melaleuca Species Grown in Tunisia." Int. J. Mol. Sci. 13 (12): 16580-91.

[45] Marques, C. A., Leitão, G. G., Bizzo, H. R., Peixoto, A. L., and Vieira, R. C. 2009. "Anatomy and Essential Oil Analysis of the Leaves from Hennecartia omphalandra (Monimiaceae).” Rev. Bras. Farmacogn. 19 (1): 95-105. (in Portuguese)

[46] Morais, L. A. S., and Castanha, R. F. 2011. "Chemical Composition of the Essential Oil of Two Samples of
Carqueja (Baccharis sp.) Collected in Paty do Alferes, Rio de Janeiro." Rev. Bras. Plantas Med. 13: 628-32. (in Portuguese)

[47] Simões-Pires, C. A., Queiroz, E. F., Henriques, A. T., and Hostettmann, K. 2005. "Isolation and Online Identification of Antioxidant Compounds from Three Baccharis Species by HPLC-UV-MS/MS with Post-Column Derivatisation." Phytochem. Anal. 16 (5): 307-14.

[48] Siqueira, N. C. S., Silva, G. A. A. B., and Alice, C. B. 1985. "Comparative Analysis of the Essential Oils of Baccharis articulata (Lam) Pers. and Baccharis trimera (Less.) DC. (Compositae), Spontaneous Species in Rio Grande do Sul." Rev. Bras. Farm. 3: 36-9. (in Portuguese)

[49] Schmidt, T. J., Bomme, U., and Alfermann, A. W. 1998. "Sesquiterpene Lactone Content in Leaves of in Vitro and Field Cultivated Arnica Montana." Planta Med. 64 (3): 268-70.

[50] Martins, E. R., Castro, D. M., and Castellani, D. C. 1995. Medicinal Plants. Viçosa: UFV, 220. (in Portuguese)

[51] Furlan, M. R. 2005. Cultivation of Medicinal Plants, 3rd ed.. Vol. 1. Cuiabá: SEBRAE, 137. (in Portuguese) 